\title{
Analisis Perbandingan Metode (Certainty Factor, Dempster Shafer dan Teorema Bayes ) untuk Mendiagnosa Penyakit Inflamasi Dermatitis Imun pada Anak
}

\author{
Puji Sari Ramadhan*, Usti Fatimah Sitorus Pane** \\ ****Program Studi Sistem Informasi, STMIK Triguna Dharma
}

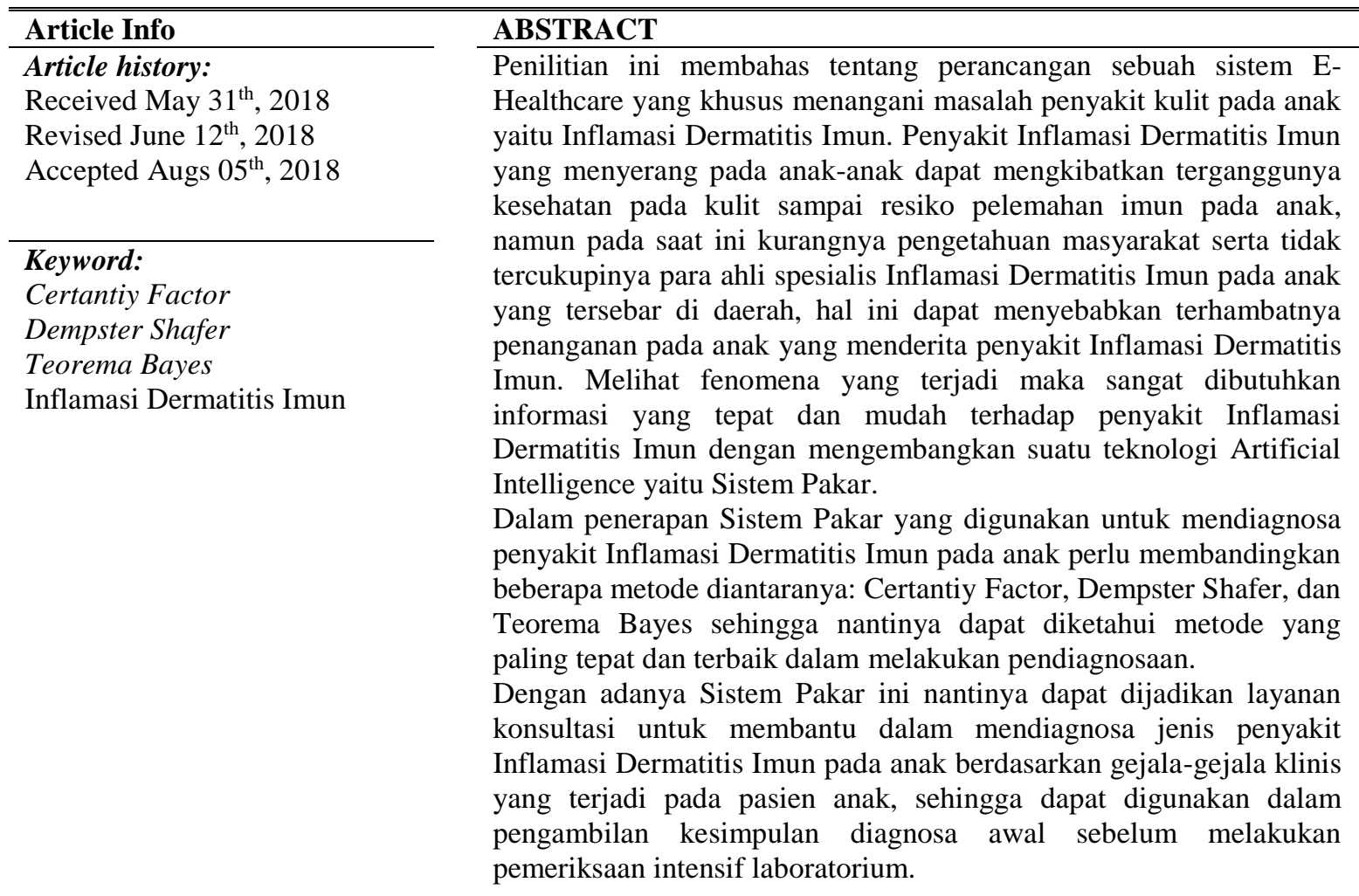

First Author

Nama: Puji Sari Ramadhan, S.Kom, M.Kom

Kantor : STMIK Triguna Dharma

Program Studi : Sistem Informasi

E-mail : pujisariramadhan@gmail.com

\section{PENDAHULUAN}

Penyakit kulit yang disebabkan oleh gangguan sistem imun adalah Inflamasi Dermatitis Imun, penyakit ini pada umumnya menyerang anak-anak dikarenakan sistem kekebalan tubuh pada anak masih lemah serta memiliki sensitifitas yang tinggi terhadap infeksi virus, lingkungan, udara dan bakteri. Penyakit Inflamasi Dermatitis Imun yang menyerang pada anak-anak dapat mengkibatkan terganggunya kesehatan pada kulit sampai resiko pelemahan imun pada anak, namun pada saat ini kurangnya pengetahuan masyarakat serta tidak tercukupinya para ahli spesialis Inflamasi Dermatitis Imun pada anak yang tersebar di daerah, hal ini dapat menyebabkan terhambatnya penanganan pada anak yang menderita penyakit Inflamasi Dermatitis Imun. Melihat fenomena yang terjadi maka sangat dibutuhkan informasi yang tepat dan mudah terhadap penyakit Inflamasi Dermatitis Imun dengan mengembangkan suatu teknologi Artificial Intelligence yaitu Sistem Pakar . 
Sistem Pakar pernah digunakan untuk mendeteksi ikan bandeng berformalin(Hadini, 2017). Selain itu, Sistem Pakar juga pernah digunakan untuk mengidentifkasi kerusakan perangakat CISCO dengan menerapkan teknik inferensi Forward Chaining(Widjaja and Susilo, 2017).

Dalam penelitian lainnya, disebutkan bahwa Sistem Pakar dapat digunakan untuk mendiagnosa penyakit Tuberkolosis(Hossain et al., 2017). Pengembangan sistem yang semakin ahli, ini ditandai dengan jumlah kasus yang diselesaikan oleh sistem pakar termasuk yang digunakan untuk mengidentifikasi patah tulang menggunakan teknik Forward Chaining(Masya, Prastiawan and Mubaroq, 2016).

Dalam penerapan Sistem Pakar yang digunakan untuk mendiagnosa penyakit Inflamasi Dermatitis Imun pada anak perlu membandingkan beberapa metode diantaranya: Certantiy Factor, Dempster Shafer, dan Teorema Bayes yang nantinya dapat digunakan untuk mengukur tingkat keyakinan pakar dan tingkat probabilitas terhadap gejala-gejala yang terjadi pada anak yang kemungkinan menderita penyakit Inflamasi Dermatitis Imun sehingga dapat diketahui metode yang paling tepat dan terbaik dalam melakukan pendiagnosaan Dengan adanya Sistem Pakar ini nantinya dapat dijadikan layanan konsultasi untuk membantu dalam mendiagnosa jenis penyakit Inflamasi Dermatitis Imun pada anak berdasarkan gejala-gejala klinis yang terjadi pada pasien anak, sehingga dapat digunakan dalam pengambilan kesimpulan diagnosa awal sebelum melakukan pemeriksaan intensif laboratorium.

\section{LANDASAN TEORITIS}

\subsection{Sistem Pakar}

Sistem pakar adalah pengembangan kecerdasan buatan dalam bentuk aplikasi praktis(Al-Ajlan, 2015). Dalam penelitian lain, dijelaskan bahwa Sistem Pakar adalah salah satu metode yang terdapat dalam kecerdasan buatan yang digunakan untuk mendiagnosis kesalahan sistem dan sebagai pemecahan masalah(Wang et al., 2015).

Definisi lain yang menjelaskan bahwa Sistem Pakar diimplementasikan untuk melakukan pemecahan masalah dan mengambil keputusan dengan pengetahuan dasar dan aturan yang diterapkan oleh sistem cerdas(Divya and Sreekumar, 2014).

Dalam jurnal lain disebutkan bahwa Sistem Pakar termasuk sekelompok kecerdasan buatan yang memiliki pengetahuan khusus dalam memecahkan masalah yang ada(Gede and Divayana, 2014).

Pendapat lain yang menunjukkan bahwa Sistem Pakar adalah hasil dari pengetahuan dan prosedur pencarian(Hossain et al., 2017).

\subsection{Certainty Factor (Faktor Kepastian)}

Metode Certainty Factor (CF) ini dipilih ketika dalam menghadapi suatu masalah, sering ditemukan jawaban yang tidak memiliki kepastian penuh. Untuk mengakomodasi hal ini maka digunakan Certainty Factor (CF) guna menggambarkan tingkat keyakinan pakar terhadap masalah yang sedang dihadapi( Nofriansyah, Ramadhan, 2016).

Berikut perhitungan Certainty Factor untuk kombinasi dua buah rule dengan evidence berbeda ( $\mathrm{E}_{1}$ dan E2), tetapi hipotesisnya sama :

$$
\mathrm{CF}\left(\mathrm{CF}_{1}, \mathrm{CF}_{2}\right)=\left[\begin{array}{cc}
\mathrm{CF}_{1}+\mathrm{CF}_{2}\left(1-\mathrm{CF}_{1}\right) & \text { Jika } \mathrm{CF}_{1} \text { dan } \mathrm{CF}_{2}>0 \\
\frac{\mathrm{CF}_{1}+\mathrm{CF}_{2}}{1-\min \left[\mathrm{CF}_{1}, \mathrm{CF}_{2}\right]} & \text { Jika } \mathrm{CF}_{1} \text { atau } \mathrm{CF}_{2}<0 \\
\mathrm{CF}_{1}+\mathrm{CF}_{2}\left(1+\mathrm{CF}_{1}\right) & \text { Jika } \mathrm{CF}_{1} \text { dan } \mathrm{CF}_{2}<0
\end{array}\right.
$$

\subsection{Dempster Shafer}

Dempster-Shafer adalah teori probabilitas yang digunakan untuk menentukan keputusan dengan menggunakan elemen eksperimental dan tingkat kepastian gejala(Maseleno and Hasan, 2013).

Teori Dempster-Shafer pertama kali diperkenalkan oleh A. Dempster yang digunakan sebagai representasi ketidaktahuan untuk mendapatkan informasi yang tepat(Fontani et al., 2013). Berikut fungsi dari Dempster Shafer :

$$
\begin{aligned}
& m_{12}(\theta)=0 \\
& m_{12}(A)=\frac{1}{1-k} \sum_{B \cap C=A \neq \theta} m_{1}(B) m_{2}(C) \\
& k=\sum_{B \cap C=\theta} m_{1}(B) m_{2}(C)
\end{aligned}
$$




\subsection{Teorema Bayes}

Teorema Bayes adalah aturan yang menggunakan probabilitas untuk menghasilkan keputusan dan informasi yang tepat(Hadini, 2017). Berikut persamaan Teorema Bayes :

$$
P\left(M_{i} \mid S\right)=\frac{P\left(S \cap M_{i}\right.}{P(S)}
$$

\subsection{Penyakit Inflamasi Dermatitis Imun}

Berdasarkan Buku Alergi-Imunologi Anak dari Ikatan Dokter Anak Indonesia, dikemukakan bahwa penyakit Inflamasi Dermatitis Imun merupakan penyakit yang sering dijumpai pada bayi dan anak, penyakit ini bersifat kronik residif biasanya disertai infeksi, alergi, faktor psikogenik, dan bahan kimia/iritan. Jenis penyakit Inflamasi Dermatitis Imun pada anak terdiri dari Eksim Dermatis, Psoriasis, dan Atopik.

\subsubsection{Eksim Dermatis}

Eksim Dermatis merupakan istilah kedokteran untuk kelainan kulit yang tampak meradang dan iritasi. Peradangan ini bisa terjadi di mana saja namun yang paling sering terkena adalah tangan dan kaki. Gejala eksim akan mulai muncul pada masa anak-anak umur di atas dua tahun. Pada beberapa kasus, eksim akan menghilang dengan bertambahnya usia, namun tidak sedikit pula yang akan menderita seumur hidupnya(Maharani, 2015).

\subsubsection{Psoriasis}

Psoriasis merupakan sejenis penyakit kulit yang penderitanya mengalami proses pergantian kulit yang terlalu cepat. Kemunculan penyakit ini terkadang untuk jangka waktu yang lama atau hilang-timbul. Penyakit ini secara klinis tidak mengancam nyawa ataupun menular, tetapi dapat menurunkan kualitas hidup dan mengganggu kekuatan imun (Maharani, 2015)

\subsubsection{Atopik}

Penyakit ini dinamakan dermatitis atopik dikarenakan kebanyakan penderitanya memberikan reaksi kulit yang didasari oleh $\operatorname{IgE}$ dan mempunyai kecenderungan untuk menderita asma, rinitis yang dikemudian hari dikenal sebagai allergic march (Maharani, 2015).

\section{ANALISIS DAN HASIL}

4.

\subsection{Analisis Permasalahan}

Dalam membangun sebuah sistem yang mampu mengadopsi proses dan cara memasukkan pengetahuan dari seorang pakar ke dalam komputer sehingga dapat memberikan kemudahan dalam mendiagnosa penyakit Inflamasi Dermatitis Imun pada anak dengan kualitas pakar, maka dibutuhkan pengolahan basis pengetahuan kepakaran dari seorang pakar yang dibentuk ke dalam aturan-aturan dan fakta-fakta yang dapat menghasilkan diagnosa dan kesimpulan sesuai dengan kaidah-kaidah basis pengetahuan yang ada. Berikut ini merupakan pembentukan aturan-aturan yang berasal dari pengetahuan pakar.

Tabel 3.1 Data Kepakaran Penyakit Inflamasi Dermatitis Imun pada Anak

\begin{tabular}{|c|l|c|c|c|}
\hline \multirow{2}{*}{ No } & \multicolumn{1}{|c|}{ Daftar Gejala } & \multicolumn{2}{|c|}{ Data Penyakit Inflamasi Dermatitis Imun Pada Anak } \\
\cline { 3 - 5 } & \multicolumn{1}{|c|}{ Eksim Dermatitis } & Psoriasis & Atopik \\
\hline 1 & $\begin{array}{l}\text { Rasa panas dan dingin yang berlebihan } \\
\text { pada bagian kulit yang terkena eksim }\end{array}$ & 0.6 & & \\
\hline 2 & Rasa gatal & 0.2 & & \\
\hline 3 & Kulit kering & 0.6 & & \\
\hline 4 & $\begin{array}{l}\text { Tampak lepuhan-lepuhan kecil (Bintil- } \\
\text { bintil air) }\end{array}$ & 0.4 & & \\
\hline 5 & Kulit bersisik & 0.2 & 0.4 \\
\hline 6 & $\begin{array}{l}\text { Bintik merah yang ditumbuhi bercak } \\
\text { lebar putih }\end{array}$ & & & \\
\hline 7 & Menyerang sendi & & 0.4 & \\
\hline 8 & Bernanah & & 0.4 & \\
\hline 9 & Badan menggigil & & & 0.4 \\
\hline 10 & Kulit pecah-pecah & & & \\
\hline
\end{tabular}

Berdasarkan data kepakaran penyakit Inflamasi Dermatitis Imun pada anak pada tabel 3.1, dapat dibentuk basis aturan (rule), adapun daftar aturan (rule) yang dibentuk adalah sebagai berikut : 
Rule 1 : IF rasa panas dan dingin yang berlebihan pada bagian kulit yang terkena eksim=Yes $A N D$ rasa gatal $=$ Yes $A N D$ kulit kering $=$ Yes $A N D$ tampak lepuhan-lepuhan kecil=Yes $A N D$ kulit bersisik=Yes THEN Penyakit $=$ Eksim Dermatitis .

Rule 2 : IF bintik merah yang ditumbuhi bercak lebar putih $=$ Yes $A N D$ menyerang sendi $=$ Yes $A N D$ bernanah $=$ Yes $A N D$ badan menggigil=Yes $T H E N$ Penyakit $=$ Psoriasis .

Rule 3 : IF rasa gatal $=$ Yes $A N D$ kulit bersisik $=$ Yes $A N D$ kulit pecah-pecah=Yes $T H E N$ Penyakit = Atopik.

\subsection{Analisis Penerapan Metode Certainty Factors}

Seorang anak menderita gejala-gejala : rasa gatal, kulit kering, dan tampak lepuhan-lepuhan kecil.

1. Menelusuri runut maju terhadap rule-rule yang ada

Rule 1 : IF rasa gatal =Yes $A N D$ kulit kering $=$ Yes $A N D$ tampak lepuhan-lepuhan kecil=Yes THEN Penyakit = Eksim Dermatitis.

Rule 3 : IF rasa gatal $=$ Yes THEN Penyakit $=$ Atopik.

Berdasarkan hasil dari proses penelusuran dengan menggunakan teknik inferensi Forward Chaining, diketahui bahwa anak tersebut menderita penyakit Inflamasi Dermatitis Imun : Eksim Dermatitis dan Atopik.

2. Melakukan proses perhitungan dengan metode Certainty Factor sesuai dengan persamaan rumus (2-1) dan identifikasi nilai kepastian gejala didapat dari tabel kepastian 5.1 :

a. Jenis Penyakit Eksim Dermatitis:

$\begin{array}{llll}\text { Rasa gatal dan kulit kering } & =0.2+0.6(1-0.2) & = & 0.68(\mathrm{CF} \text { kom }) \\ \text { Cf kom dan lepuhan kecil } & =0.68+0.4(1-0.68) & = & 0.80(\text { Hasil CF })\end{array}$

Maka hasil dari perhitungan dengan metode Certainty Factor untuk penyakit Eksim Dermatitis adalah 0.80 atau $80 \%$.

b. Jenis Penyakit Atopik:

Rasa gatal $=0.4+0(1-0.4)=0.4($ Hasil CF $)$

Maka hasil dari perhitungan dengan metode Certainty Factor untuk penyakit Atopik adalah 0.4 atau 40 $\%$.

3. Kesimpulan Perhitungan

Nilai Max $($ Eksim Dermatitis dan Atopik $)=(0.80 ; 0.4)=0.80$

Maka hasil diagnosa yang didapat atas kasus tersebut, bahwa pasien anak kemungkinan besar menderita penyakit Inflamasi Dermatitis Imun dengan jenis penyakit Eksim Dermatitis dengan tingkat probabilitas terhadap penyakit tesebut adalah 0.80 atau $80 \%$

3.3 Analisis Penerapan Metode Dempster Shafer

Seorang anak menderita gejala-gejala : rasa gatal, kulit kering, dan tampak lepuhan-lepuhan kecil.

1. Menelusuri runut maju terhadap rule-rule yang ada

Rule $1 \quad$ : IF rasa gatal $=$ Yes $A N D$ kulit kering $=$ Yes $A N D$ tampak lepuhan-lepuhan kecil=Yes THEN Penyakit = Eksim Dermatitis.

Rule 3 : IF rasa gatal $=$ Yes THEN Penyakit $=$ Atopik .

Berdasarkan hasil dari proses penelusuran dengan menggunakan teknik inferensi Forward Chaining, diketahui bahwa anak tersebut menderita penyakit Inflamasi Dermatitis Imun : Eksim Dermatitis dan Atopik.

2. Melakukan proses perhitungan dengan metode Dempster Shafer sesuai dengan persamaan rumus (2-2) dan identifikasi nilai kepastian gejala didapat dari tabel kepastian 3.1 :

a. Jenis Penyakit Eksim Dermatitis:

Rasa gatal dan kulit kering $\quad=(0.2 * 0.6) /(1-(0.8 * 0.4))=0.17$ (DS kom)

DS kom dan lepuhan kecil $\quad=(0.17+0.4) /(1-(1-0.68))=0.14($ Hasil DS $)$

Maka hasil dari perhitungan dengan metode Dempster Shafer untuk penyakit Eksim Dermatitis adalah 0.14 atau $14 \%$.

b. Jenis Penyakit Atopik:

Rasa gatal $=0.4 /(1-0.4) \quad=0.6($ Hasil DS $)$

Maka hasil dari perhitungan dengan metode Dempster Shafer untuk penyakit Atopik adalah 0.6 atau $60 \%$.

3. Kesimpulan Perhitungan

Nilai Max $($ Eksim Dermatitis dan Atopik $)=(0.14 ; 0.6)=0.6$

Maka hasil diagnosa yang didapat atas kasus tersebut, bahwa pasien anak kemungkinan besar menderita penyakit Inflamasi Dermatitis Imun dengan jenis penyakit Atopik dengan tingkat probabilitas terhadap penyakit tesebut adalah 0.60 atau $60 \%$.

3.4 Analisis Penerapan Metode Teorema Bayes

Seorang anak menderita gejala-gejala : rasa gatal, kulit kering, dan tampak lepuhan-lepuhan kecil. 
1. Menelusuri runut maju terhadap rule-rule yang ada

Rule 1 : IF rasa gatal =Yes $A N D$ kulit kering $=$ Yes $A N D$ tampak lepuhan-lepuhan kecil=Yes THEN Penyakit $=$ Eksim Dermatitis.

Rule 3 : IF rasa gatal $=$ Yes THEN Penyakit $=$ Atopik .

Berdasarkan hasil dari proses penelusuran dengan menggunakan teknik inferensi Forward Chaining, diketahui bahwa anak tersebut menderita penyakit Inflamasi Dermatitis Imun : Eksim Dermatitis dan Atopik.

2. Melakukan proses perhitungan dengan metode Teorema Bayes sesuai dengan persamaan rumus (2-3) dan identifikasi nilai kepastian gejala didapat dari tabel kepastian 5.8 :

a. Jenis Penyakit Eksim Dermatitis:

Rasa gatal, kulit kering, dan lepuhan kecil

$(\mathrm{P} \mid \mathrm{H} 1)=0.2 / 1.2=0.167$

$(\mathrm{P} \mid \mathrm{H} 2)=0.6 / 1.2=0.5$

$(\mathrm{P} \mid \mathrm{H} 3)=0.4 / 1.2=0.33$

$\mathrm{P}(\mathrm{E} \mathrm{Hk}) \times \mathrm{P}(\mathrm{Hk})=(0.2 * 0.167)+(0.6 * 0.5)+(0.4 * 0.33)=0.467$

$\mathrm{P}(\mathrm{H} 1 \mid \mathrm{E})=(0.2 * 0.467) / 0.467=0.07$

$\mathrm{P}(\mathrm{H} 2 \mid \mathrm{E})=(0.6 * 0.5) / 0.467 \quad=0.64$

$\mathrm{P}(\mathrm{H} 3 \mid \mathrm{E})=(0.4 * 0.33) / 0.467 \quad=0.29$

EBayes $=(0.2 * 0.07)+(0.6 * 0.64)+(0.4 * 0.29)=0.51$ (Hasil Bayes $)$

Maka hasil dari perhitungan dengan metode Teorema Bayes untuk penyakit Eksim Dermatitis adalah 0.51 atau $51 \%$.

b. Jenis Penyakit Atopik:

$(\mathrm{P} \mid \mathrm{H} 1)=0.6 / 0.6=1$

$\mathrm{P}(\mathrm{H} 1 \mid \mathrm{E}) \quad=(0.6 * 1) / 1=0.6$

¿Bayes $=(0.6 * 0.6)=0.36$ (Hasil Bayes)

Maka hasil dari perhitungan dengan metode Teorema Bayes untuk penyakit Atopik adalah 0.36 atau $36 \%$.

3. Kesimpulan Perhitungan

Nilai Max $($ Eksim Dermatitis dan Atopik $)=(0.51 ; 0.36)=0.51$

Maka hasil diagnosa yang didapat atas kasus tersebut, bahwa pasien anak kemungkinan besar menderita penyakit Inflamasi Dermatitis Imun dengan jenis penyakit Eksim Dermatitis dengan tingkat probabilitas terhadap penyakit tesebut adalah 0.51 atau $51 \%$.

\subsection{Hasil Perbandingan Metode}

Setelah melakukan perhitungan dengan menggunakan metode Certainty Factor, Dempster Shafer, dan Teorema Bayes, maka proses selanjutnya adalah menentukan metode yang paling tepat dan baik untuk melakukan pendiagnosaan penyakit Inflamasi Dermatitis Imun pada anak. Berdasarkan hasil dari perhitungan ketiga metode tersebut, maka diperoleh kesimpulan sebagai berikut :

1. Pada perhitungan dengan metode Certainty Factor penyakit yang terpilih adalah Eksim Dermatitis dengan nilai probabilitas 0.80, sementara untuk metode Dempster Shafer mendapatkan nilai probabilitas 0.6 untuk penyakit Atopik, dan metode Teorema Bayes menyimpulkan bahwa penyakit yang terpilih adalah Eksim Dermatitis dengan nilai probabilitas 0.51. Dari hasil tersebut maka metode Certainty Factor adalah metode yang memiliki nilai probabilitas tertinggi dari metode Dempster Shafer dan Teorema Bayes.

2. Dari tahapan perhitungan tingkat kepastian dengan menggunakan metode Certainty Factor, Dempster Shafer dan Teorema Bayes untuk data lebih dari 2 evidence, harus dilakukan perulangan beberapa kali dalam pengolahan dan perhitungan data kombinasi.

3. Dalam kasus mengidentifikasi jenis penyakit Inflamasi Dermatitis Imun pada anak, metode Certainty Factor dan Teorema Bayes, memiliki kesamaan pola ini terlihat dari hasil yang diperoleh yaitu jika gejala semakin banyak maka nilai probabilitas jenis penyakit akan semakin tinggi, berbeda halnya dengan metode Dempster Shafer yang semakin banyak gejala yang dipilih maka akan menghasilkan nilai probabilitas yang semakin kecil pula bahkan nilai probabilitas satu gejala dapat lebih tinggi dibandingkan dengan nilai probabilitas dengan gejala yang lebih dari satu. Namun untuk metode Teorema Bayes nilai probabilitas yang diperoleh lebih kecil dibandingkan dengan nilai probabilitas metode Certainty Factor. Dengan hasil ini maka untuk mendiganosa penyakit Inflamasi Dermatitis Imun pada anak, metode yang paling tepat dan baik adalah metode Certainty Factor. Hal ini sesuai dengan ilmu kepakaran bahwa satu penyakit tidak dapat ditetapkan hanya dengan satu gejala atau dengan kata lain nilai probabilitasnya rendah dan semakin banyak gejala-gejala yang diderita maka semakin mungkin terdiagnosa jenis penyakit tersebut dengan nilai probabilitasnya yang tinggi. 


\section{KESIMPULAN}

Berdasarkan hasil pembahasan tentang implementasi analisis perbandingan metode Certainty Factor, Dempster Shafer, dan Teorema Bayes yang telah dikemukakan, maka dapat diperoleh beberapa kesimpulan, adapun kesimpulan tersebut adalah sebagai berikut :

1. Berdasarkan hasil perhitungan yang telah dilakukan maka dapat diketahui bahwa metode Certainty Factor adalah metode yang memiliki nilai probabilitas tertinggi dari metode Dempster Shafer dan Teorema Bayes.

2. Dengan hasil perhitungan ini maka nantinya implementasi sistem pakar untuk mendiagnosa penyakit Inflamasi Dermatitis Imun pada Anak adalah dengan menggunakan metode Certainty Factors

\section{DAFTAR PUSTAKA}

Al-Ajlan, A. (2015) 'The Comparison between Forward and Backward Chaining', International Journal of Machine Learning and Computing, 5(2), pp. 106-113. doi: 10.7763/IJMLC.2015.V5.492.

Dicky Nofriansyah, Puji Sari Ramadhan, B. A. (2016) 'Perancangan Aplikasi Sistem Pakar untuk Mendeteksi Jenis Racun dan Spesies Ular pada Pasien yang Terkena Racun Bisa Ular Menggunakan Metode Certainty Factor', Jurnal Saintikom, 14, pp. 93-104.

Divya, J. and Sreekumar, K. (2014) 'A Survey on Expert System in Agriculture', International journal of computer science and information technologies, 5(6), pp. 7861-7864.

Fontani, M. et al. (2013) 'A Framework for Decision Fusion in Image Forensics Based on Dempster Theory of Evidence', IEEE Transactions on Information Forensics and Security, 8(4), pp. 593-607. doi: 10.1109/TIFS.2013.2248727.

Gede, D. and Divayana, H. (2014) 'Application of Pineapple Diseases Expert System with FC-FL Method at Badung Regency Agriculture Department’, 4(8), pp. 293-298.

Hadini, F. M. (2017) 'Detection System Milkfish Formalin Android-Based Method Based on Image Eye Using Naive Bayes Classifier', 9(1), pp. 2-5.

Hossain, M. S. et al. (2017) 'A Belief Rule Based Expert System to Assess Tuberculosis under Uncertainty', Journal of Medical Systems. Journal of Medical Systems, 41(3). doi: 10.1007/s10916-017-0685-8.

Maharani, A. (2015) Penyakit Kulit. Edited by MOna. Yogyakarta: Pustaka Baru Press.

Maseleno, A. and Hasan, M. (2013) 'The Dempster-Shafer Theory Algorithm and its Application to Insect Diseases Detection', 50, pp. 111-120.

Masya, F., Prastiawan, H. and Mubaroq, S. (2016) 'Application Design to Diagnosis of Bone Fracture ( Traditional ) using Forward Chaining Methods', International Research Journal of Computer Science (IRJCS), 3(09), pp. 23-30.

Wang, T. et al. (2015) 'Fault Diagnosis of Electric Power Systems Based on Fuzzy Reasoning Spiking Neural P Systems', IEEE Transactions on Power Systems, 30(3), pp. 1182-1194. doi: 10.1109/TPWRS.2004.836256.

Widjaja, A. and Susilo, A. B. (2017) 'EXPERT SYSTEM TO IDENTIFY DAMAGE CISCO AS5300 DEVICE WITH THE METHOD OF FORWARD CHAINING-BASED CLIENT-’, 9, pp. 787-805.

\section{BIBLIOGRAFI PENULIS}

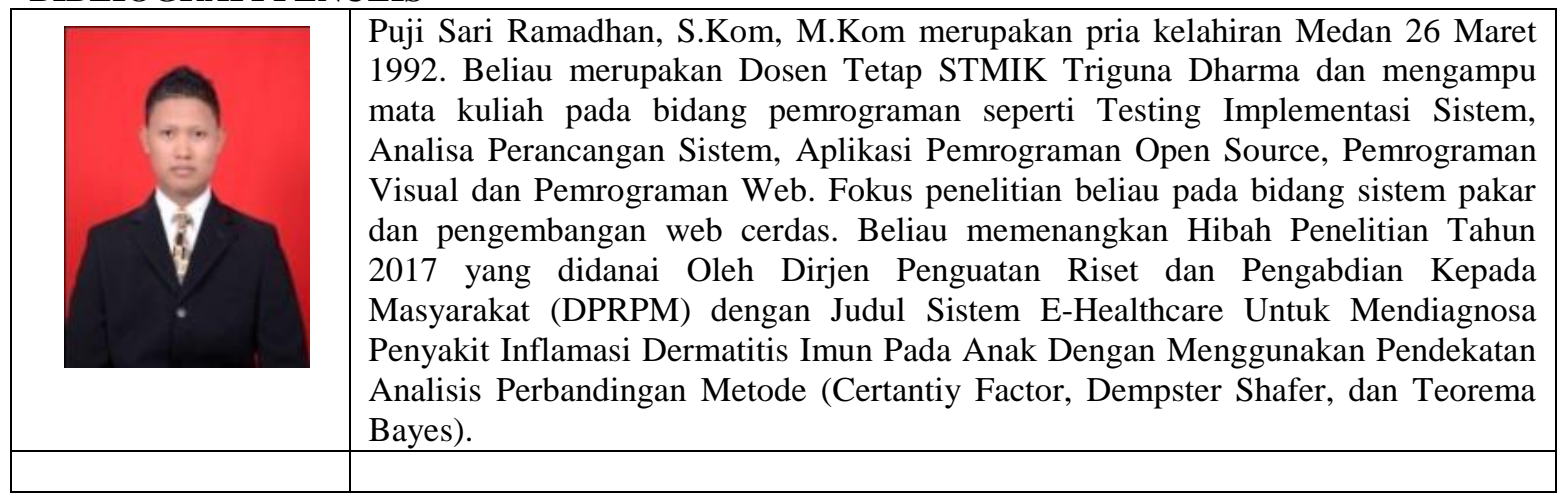




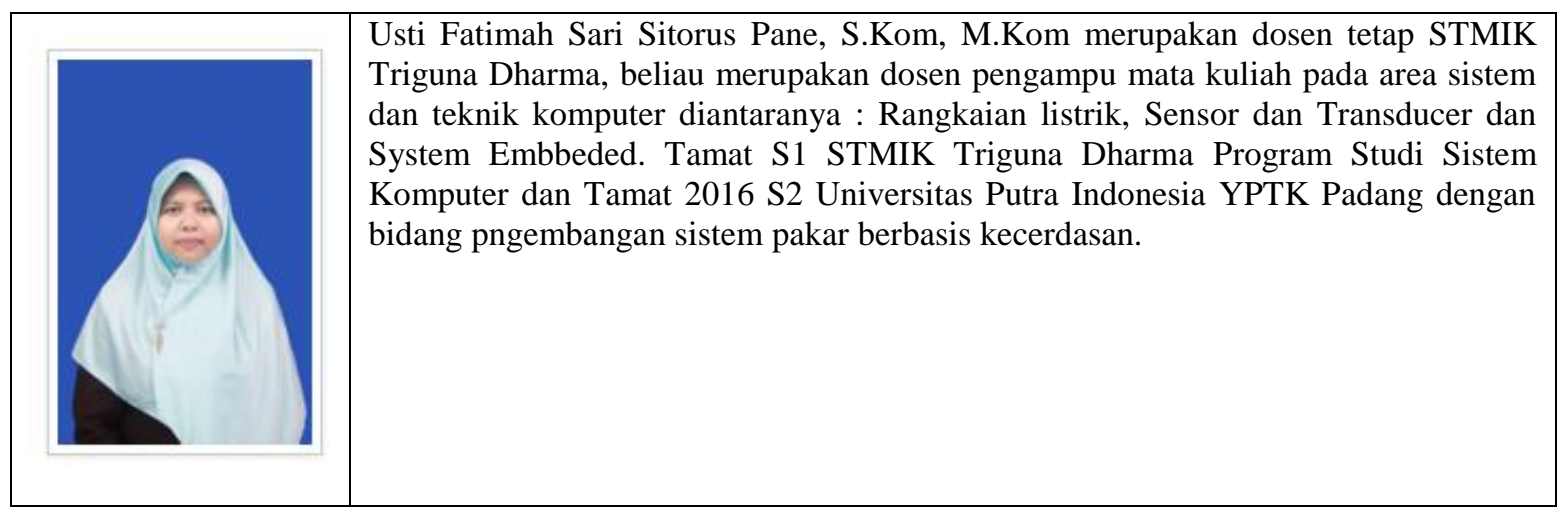

